\title{
Clinical value of ELISA assays for IgM and IgG rheumatoid factors
}

\author{
R STONE, J S COPPOCK, * P T DAWES, $†$ P A BACON,* D L SCOTT \\ From the Department of Rheumatology, St Bartholomew's Hospital, London, the †Staffordshire Rheumatology \\ Centre, Haywood Hospital, and *The Rheumatism Research Wing, The Medical School, Birmingham
}

SUMMARY The clinical value of enzyme linked immunosorbent assays (ELISA) assays for IgM and IgG rheumatoid factors was assessed in a series of studies using rabbit IgG as antigen. The tests were reproducible with intra-assay coefficients of variation of $6 \%$ and could be simply and rapidly performed. Normal ranges were established using 106 sera from healthy controls. In a cross sectional study of 208 rheumatoid patients these assays were compared with the Rose-Waaler and laser nephelometric assessments of rheumatoid factor. In some patients there were discrepancies between rheumatoid factor positivity determined by one method or another. IgM ELISA and Rose-Waaler titres showed a significant correlation $(\mathrm{r}=+0.58 ; \mathrm{p}<0.001)$, but there was a low correlation between IgM and IgG ELISA $(r=+0.27$; $p<0.001)$. There was no evidence to show that the measurement of IgM or IgG rheumatoid factor gave significantly more clinical information than traditional tests such as the Rose-Waaler or latex agglutination tests.

Rheumatoid factors can be of any antibody class. ${ }^{1}$ Established methods for their routine assessments, such as the latex and sheep red cell agglutination methods ${ }^{2-4}$ have disadvantages. They measure rheumatoid factors as a discontinuous titre and may be insensitive to changes. They also predominantly measure IgM rheumatoid factor as it has the greatest agglutinating ability. To overcome these problems new rheumatoid factor assays have been developed. These include laser nephelometry, ${ }^{5}$ radioimmunoassay, ${ }^{6-9}$ and enzyme linked immunoabsorbent assay (ELISA) ${ }^{10-18}$ Should these new assays be routinely introduced into rheumatological laboratories? We examined this clinically important question by studying a large number of sera from patients with established rheumatoid arthritis using a simple ELISA assay system. If this system is to be widely used it should not only be reproducible and simple, but also have substantial advantages over latex and red cell agglutination assays.

\section{Patients and methods}

\section{SAMPLES}

Sera were collected from three groups of patients and controls and stored at $-20^{\circ} \mathrm{C}$ until analysed.

Accepted for publication 8 July 1986

\section{Control specimens}

Healthy control specimens were kindly provided by the Regional Blood Transfusion Service in Birmingham. One hundred and six sera were randomly selected; 60 of these were from donors screened to exclude joint disease and recent infection.

\section{Patients}

One hundred and sixty patients with classical or definite rheumatoid arthritis (defined by the criteria of the American Rheumatism Association) and with a Rose-Waaler titre of $1 / 32$ or greater, termed seropositive, were studied, as were 48 patients with an arthropathy of a rheumatoid pattern but a persistently negative Rose-Waaler titre of $1 / 16$ or less (measured repeatedly over one year), termed seronegative.

\section{ROSE-WAALER AND NEPHELOMETRIC TESTS}

The Rose-Waaler test was performed by the standard laboratory method described by Thompson. ${ }^{19}$ Laser nephelometry was undertaken as described by Roberts-Thompson et $\mathrm{al}^{5}$ : serum diluted $1 / 25$ in phosphate buffered saline was reacted with 100 litres of heat aggregated human IgG. The mixture was stirred and allowed to stand at room temperature for 60 minutes. The degree of light scatter was measured in a laser nephelometer (Behring Diagnostics) and expressed in millivolts. From this value was subtracted the scatter caused by the $1 / 25$ serum dilution 
alone without heat aggregated immunoglobulin and the scatter caused by heat aggregated immunoglobulin. All measurements were made in duplicate.

IgM RHEUMATOID FACTOR ELISA ASSAY

Microtitre plates (Linbro, Flow Laboratories) were coated with $0.1 \mathrm{ml}$ rabbit IgG (Sigma) at $0.03 \mathrm{mg} / \mathrm{ml}$ in coating buffer containing $1.59 \mathrm{~g}$ sodium carbonate and $2.93 \mathrm{~g}$ sodium bicarbonate in 1 litre at $\mathrm{pH} 9.6$. Non-specific binding was blocked by $1 \%$ bovine serum albumin (Sigma) in coating buffer. The plates were left overnight at $4^{\circ} \mathrm{C}$. After extensive washing $0.1 \mathrm{ml}$ diluted test serum was added to the wells in triplicate and left for one hour at room temperature. The plates were washed five times and $0.1 \mathrm{ml}$ diluted peroxidase conjugated antihuman IgM (Dakopatts) was added to each well and left for two hours at $4^{\circ} \mathrm{C}$. The plates were again washed and $0.2 \mathrm{ml}$ of freshly prepared substrate solution (orthophenyl-diamine in citrate buffer, $\mathrm{pH} 5.0$ ) added. The colour reaction was stopped at 30 minutes with $0.025 \mathrm{ml}$ of $20 \%$ sulphuric acid. The absorbance were read using a Multiscan (Titertek) plate reader at $490 \mathrm{~nm}$. Appropriate reagent blanks and positive and negative control serum samples were included on every plate.

IgG RHEUMATOID FACTOR ELISA ASSAY

An identical method was used, except horseradish peroxidase conjugated antiglobulin directed to $\mathrm{IgG}$ (Dakopatts) was added instead of anti-IgM.

PRELIMINARY STUDIES WITH ELISA ASSAY

Initial experiments evaluated four different plates obtained from Linbro, Nunc, Falcon, and Dynotec. The Linbro plates were the most satisfactory. Other plates produced various problems, including high background binding of serum and poorer reproducibility between wells.

Coating with $<0.01 \mathrm{mg}$ per $\mathrm{ml}$ and with $>0.1 \mathrm{mg}$ per $\mathrm{ml}$ of rabbit IgG gave poor reproducibility. Rabbit IgG $(0.03 \mathrm{mg} / \mathrm{ml})$ was optimal. A serum dilution was chosen on the linear portion of the sigmoidal curve obtained when absorbance was plotted against serum dilutions. One hour of incubation of the test sample was the most advantageous. The dilution of the conjugated anti-immunoglobulin was chosen on the linear portion of the sigmoidal curve obtained when the absorbant was plotted against conjugated anti-immunoglobulin dilution. The incubation time of the conjugated immunoglobulin was chosen on the basis of time curve for binding; two hours was best for repeat samples.

Coefficients of variation were calculated over eight assays and were as follows: IgM ELISA intra-assay coefficient of variation was $6 \%$ and interassay coefficient of variation $8 \%$; IgG ELISA intra-assay coefficient of variation was $6 \%$ and interassay coefficient of variation was $15 \%$.

The upper end of the reference ranges for IgM and IgG rheumatoid factors were the 95 percentiles of the control population. These were 0.27 absorbance units for IgM rheumatoid factor and 0.45 for IgG rheumatoid factor. IgG ELISA rheumatoid factors, excluding controls with evidence of joint disease and recent infection, caused a fall in the reference range to 0.35 absorbance units, but this lower reference range was not used in the present study. There was no similar effect with the IgM ELISA assay.

\section{Results}

CLINICAL EVALUATION OF THE IgM ELISA

The overall spread of results from the patients with rheumatoid arthritis in the cross sectional study and the normal controls were compared, grouping the rheumatoid patients into seropositive and seronegative by the Rose-Waaler method. Fig 1 summarises the results. Detailed analysis of the areas of disagreement showed that of the 160 seropositive patients (Rose-Waaler method) $82 \%$ were positive by the ELISA technique for IgM rheumatoid factor and $18 \%$ were negative. Of the 48 seronegative patients, $30 \%$ were positive by the IgM ELISA and $70 \%$ negative.

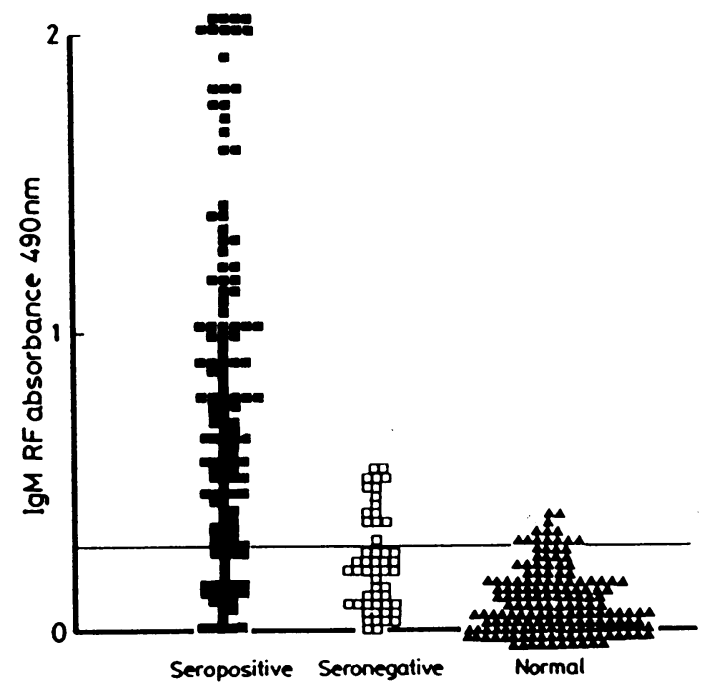

Fig 1 IgM ELISA rheumatoid factor in 208 patients with rheumatoid factors and 106 controls. Patients are divided into seropositive by the Rose-Waaler method $(n=160)$ and persistently seronegative $(n=48)$. Upper limit of normal (control mean plus 2 standard deviations) is indicated by solid line. 


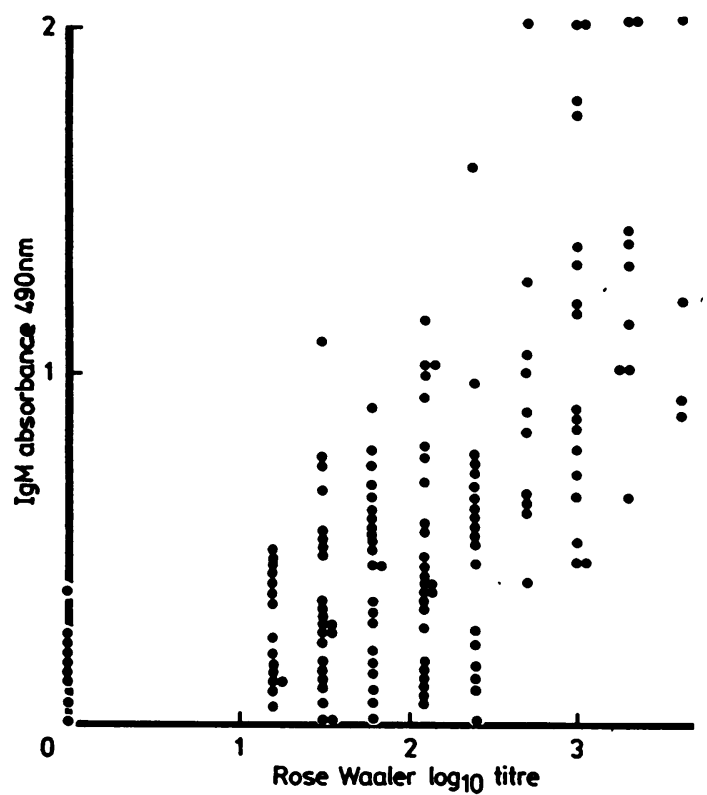

Fig 2 Relation of IgM ELISA rheumatoid factor and Rose-Waaler titre in 175 patients with rheumatoid factors. Correlation was highly significant $(r=+0.58 ; p<0.001)$.

\section{COMPARISON OF IgM ELISA USING THE} ROSE-W AALER METHOD

There was a reasonably close correlation in 175 of the 208 studied cross sectionally (Pearson's correlation coefficient $r=+0.58 ; p<0.001$ ) (fig 2). These cases were the first 175 patients evaluated. Despite this highly significant relation several patients with relatively high titres of rheumatoid factor (Rose-Waaler method) were negative by the IgM ELISA technique. Furthermore, at each level of dilution in the haemagglutination assay there was a wide range for comparative measures using the ELISA assay.

\section{COMPARISON OF IGM ELISA WITH LASER NEPHELOMETRY}

This comparison was only undertaken in 41 patients randomly selected from the cross sectional study. There was a significant correlation (Pearson's correlation coefficient $r=+0.50$; $p<0.001$ ). As with comparisons between IgM, ELISA, and Rose-Waaler titre, there was considerable individual variation in the results obtained by the IgM ELISA technique and those given by laser nephelometry.

THE RELATION BETWEEN IgM AND IgG ELISA ASSA Y

The IgM ELISA assay showed only a weak relation

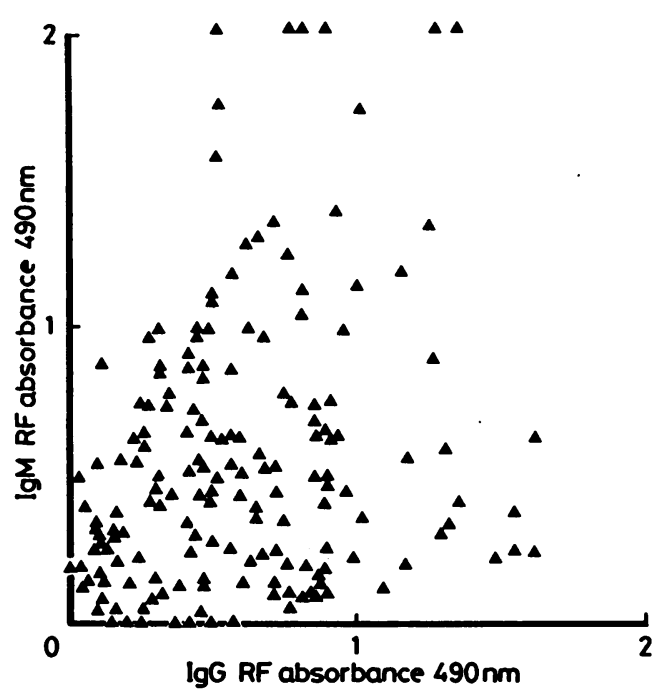

Fig 3 Relations of IgM and IgG ELISA rheumatoid factor in 175 patients with rheumatoid factors. There was only a weak correlation, though this was significant $(r=+0 \cdot 27$; $p<0.001$ ).

with the IgG assay in 175 patients from the cross sectional study (fig 3); although there was a significant relation, the correlation was low (Pearson's coefficient correlation $\mathrm{r}=+0.27 ; \mathrm{p}=<0.001)$.

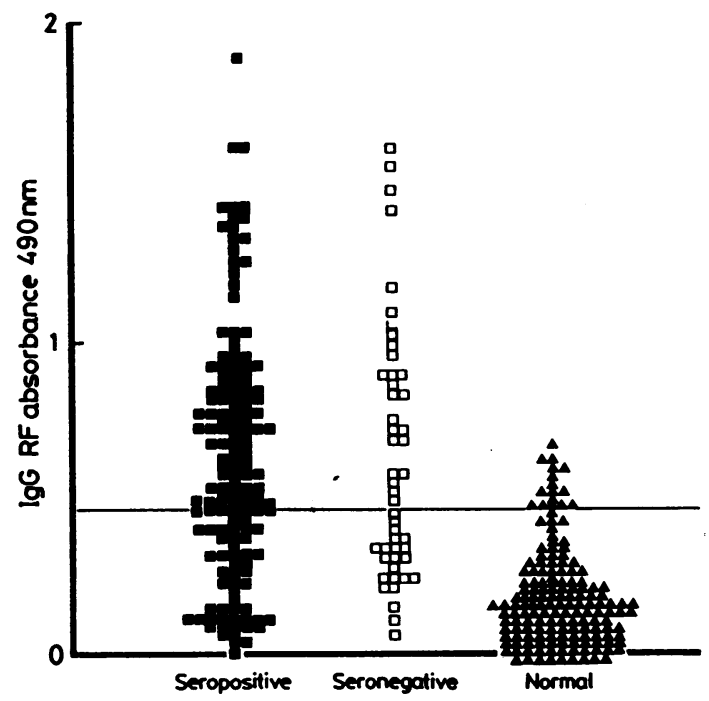

Fig 4 IgG ELISA rheumatoid factor in 208 patients with rheumatoid arthritis and in 106 controls. 
CLINICAL EVALUATION OF THE IgG ELISA ASSAY

A similar examination was undertaken to that for the IgM ELISA assay. This showed that there was no close relation between the results of the patients assessed as seropositive by the Rose-Waaler assay and of the IgG ELISA results (fig 4). Of the 160 patients classified as seropositive by the Rose-Waaler method, $67 \%$ were also positive by the IgG ELISA assay and $33 \%$ negative. Of the 48 patients classified as seronegative by the Rose-Waaler assay, $54 \%$ were positive by the IgG ELISA assay and $46 \%$ negative.

\section{Discussion}

The ELISA system we used is simple and technically acceptable. It is reproducible with low intra-assay coefficient of variations of $6 \%$. The correlations of the ELISA IgM rheumatoid factor assay with the Rose-Waaler titre and laser nephelometric measures of rheumatoid factor suggest that the assay is a true measure of rheumatoid factor. We used a single simple dilution of serum as we felt this was the most practical policy for a rapid simple assay system. Complexed rheumatoid factors may not be detected by solid phase assays, and serum can be treated with acid to eliminate this. When we examined this problem in a small number of cases in a preliminary study we found no evidence of a significant effect in our ELISA assay when serum was treated with acid. For the selection of reference ranges, we used the mean plus two standard deviations from 106 control sera. This gave a relatively high reference range for IgG rheumatoid factors; if people with evidence of joint disease and recent infection were excluded the reference range for IgG rheumatoid factor fell substantially; IgM rheumatoid factor was not similarly influenced. We considered that the higher reference range may have given greater disease specificity.

Techniques for class specific rheumatoid factor assays vary with both ELISA and radioimmunoassay methods. The source of IgG includes rabbits, humans, and other species of primate. ${ }^{2021}$ With human IgG, technical problems have led to the use of Fc fragments for coating plates with labelled antisera directed to the Fab fragment in the final stage of the sandwich. ${ }^{2223}$ Some assays detect subclasses of $\mathrm{IgG},{ }^{24}$ or rheumatoid factors of $\operatorname{IgA}$ and $\operatorname{IgE}$ classes. $^{2526}$ Our own assay system using rabbit IgG as the coating antigen was designed to be a simple method and is comparable with the standard RoseWaaler method.

The existence of many varied solid phase methods militates against the introduction of any single new assay system into routine clinical practice. There are theoretical drawbacks to solid phase assays for quan- tifying rheumatoid factors. IgG bound to a solid phase is prone to non-specific adsorption of other IgG molecules and immune aggregates. ${ }^{27}$ This may be a problem with our own ELISA IgG rheumatoid factor assay. The washing steps used to remove the unbound proteins may dissociate rheumatoid factors of low association constants bound to the immobilised IgG. These theoretical disadvantages do not seem to have a major practical impact as the number of seropositive cases by different techniques is broadly similar. IgM rheumatoid factors can interfere with the measurement of IgG rheumatoid factors in solid phase assays. It has been suggested that treating serum with pepsin digestion ${ }^{72}$ or a reducing agent $^{628}$ would overcome this. Variable results, however, have been reported using this approach, especially with reduction and alkylation of serum. Our view is that this step is best omitted if the objective is to produce a simple, rapid, and reproducible assay. Bampton et al $^{16}$ have shown that pepsin treatment reduces IgG rheumatoid factor values in an ELISA system, but it is difficult to be certain how specific an effect such treatment has on IgM interference, and how much is an inhibition in the assay's detection of IgG rheumatoid factors due to nonspecific protein degradation by pepsin.

The measurement of specific classes of rheumatoid factors has given useful experimental information on questions such as the response to antirheumatic drugs, ${ }^{31}$ the possible prediction of erosive disease, ${ }^{32}$ and the pathogenesis of rheumatoid vasculitis, ${ }^{33} 34$ but this is different from routine laboratory practice.

Before new tests are widely introduced they should have a clear advantage which outweighs the confusion associated with changes in laboratory measures. Our results show that this is not currently the case with ELISA assays for IgM or IgG rheumatoid factor. There is a clear divergence between the large numbers of reports of new assays for rheumatoid factors and what most routine immunology laboratories undertake for clinical diagnostic purposes. Most centres still use the latex and Rose-Waaler tests, or simple variants of these. Our own results and those of most other clinical evaluations show that ELISA assays or nephelometric assays ${ }^{35}$ are as good as the Rose-Waaler titre. But they are not better tests in terms of providing substantially more clinical information. They also have a weakness in determining the limits of normality; and they are weakest at the lower levels of their range. ${ }^{36}$ Because clinicians are used to the standard latex and Rose-Waaler tests, there is information relating these tests to prognosis over several years, ${ }^{37}$ and their widespread use gives a degree of clinical and laboratory standardisation, so we recommend that they are not replaced by new ELISA assays for routine clinical work: there would 
be no appreciable advantage in doing so.

Finally, our results show that any division of rheumatoid patients into the clearly defined groups of seropositive and seronegative cases is illogical as with different tests for rheumatoid factor the division will change.

We are grateful for the support of the Arthritis and Rheumatism Council and the Joint Research Board of St Bartholomew's Hospital. We thank Drs MF Shadforth, PD Fowler, and DGI Scott for their help with collecting the clinical specimens.

\section{References}

1 Mannik M. Rheumatoid factors. In: McCarty DJ, ed. Arthritis and allied conditions. 10th Ed. Philadelphia: Lea and Febiger, 1985:660-7.

2 Waaler E. On the occurrence of a factor in human serum activating the specific agglutination of sheep blood corpuscles. Acta Pathol Microbiol Scand 1940;17:172.

3 Rose HM, Ragan C, Pearce E, Lipman MO. Differential agglutination of normal and sensitised sheep erythrocytes by sera of patients with rheumatoid arthritis. Proc Soc Exp Biol Med 1948;68:1-6.

4 Singer JM, Plotz CM. The latex fixation test. Am J Med 1956;21:888-92.

5 Roberts-Thompson PJ, Wernick PM, Ziff M. Quantitation of rheumatoid factor by laser nephelometry. Rheumatol Int 1982;2:17-20.

6 Carson DA, Lawrence S, Cataland MA, Vaughan JH, Abraham G. Radioassay of IgG and IgM rheumatoid factors reacting with human IgG. J Immunol 1977;119:295-300.

7 Wernick R, Lospalluto JJ, Fink CW, Ziff M. Serum IgG and IgM rheumatoid factors by solid-phase radioimmunoassay. Arthritis Rheum 1981;24:1501-11.

8 Nordfang $\mathrm{O}$, Hoier-Madsen M, Halberg P, Lieberkind J. A new radioimmunoassay for IgM and IgG rheumatoid factors, based on a double antibody method. I Immunol Methods 1981;47:87-97.

9 Koopman WJ, Schrohenloher RE. A sensitive radioimmunoassay for quantitation of IgM rheumatoid factor. Arthritis Rheum 1980;23:302-6.

10 Vejtorp M, Hoier-Madsen M, Halberg P. Enzyme-linked immunosorbent assay for determination of IgM rheumatoid factor. Scand J Rheumatol 1979;8:59-63.

11 Karsh J, Halbert SD, Klima E, Steinberg AD. Quantitative determination of rheumatoid factors by an enzyme-linked immunosorbent assay. J Immunol Methods 1980;32:115-26.

12 Faith A, Pontesillia G, Vriger A, Panayi GS, Johns P. ELISA assays for IgM and IgG rheumatoid factors. $J$ Immunol Methods 1982;55:167-77.

13 Paloscio T, Milgram F. IgG RF detection by EIA in RA and normal subjects. J Immunol Methods 1981;41:171-81.

14 Zoila B, Tuokko H. Solid phase enzyme immunoassay of IgMclass rheumatoid factor. Acta Pathol Microbiol Scand (Sect C) 1980;88:127-30.

15 Ishimaki I, Watenable S, Yoshida H, Kasukana R. Immunoglobulin class of rheumatoid factors detected by enzymelinked immunosorbent assay. Clin Rheumatol 1983;2:145-51.

16 Bampton JLM, Canston TE, Kyle MV, Hazleman BL. Measurement of rheumatoid factors by an enzyme-linked immunosorbent assay (ELISA) and comparisons with other methods. Ann Rheum Dis 1985;44:13-19.

17 Togun RA, Brenchley P. Some factors affecting the quantitation of rheumatoid factors by enzyme immunoassay. I Immunol Methods 1983;65:343-50.

18 Teitsson I, Valdimarsson H. Use of monoclonal antibodies and F (ab) enzyme conjugates in ELISA for IgM, IgA and IgG rheumatoid factors. J Immunol Methods 1984;71:149-61.

19 Thompson RA. Techniques in clinical immunology. 2nd Ed. Oxford: Blackwell Scientific Publications, 1981.

20 Stewart GA, Hynneyball IM, Stanworth DR. The use of baboon IgG-sensitised sheep erythrocytes as an alternative indicator system in the study of the interaction of rheumatoid factor with human IgG. Imimunochemistry 1975;12:647-62.

21 Allen C, Elson CJ, Scott DGI, Bacon PA, Bucknall RC. IgG antiglobulins in rheumatoid arthritis and other arthritides: relationship with clinical features and other parameters. Ann Rheum Dis 1981;40:127-31.

22 Powell RJ, Leyland AM, Pound JD, Bossingham DH. An improved assay for IgG rheumatoid factor: its value in the diagnosis of rheumatoid arthritis. J Rheumatol 1985;12: 427-31.

23 Elson CJ, Carter SD, Scott DGI, Bacon PA, Lowe J. A new assay for IgG rheumatoid factor activity and its use to analyse rheumatoid factor reactivity with human IgG isotypes. Rheumatol Int 1985;5:175-9.

24 Robbins DL, Wister R. Comparative specificities of serum and synovial cell 19S IgM rheumatoid factors in rheumatoid arthritis. Arthritis Rheum 1985;28:S100.

25 Elkon KB, Delacroix DL, Gharvi AE, Vaerman JP, Hughes GRV. Immunoglobulin $A$ and polymeric IgA rheumatoid factors in systemic sicca sỳndrome: partial characterisation. J Immunol 1982;129:576-81.

26 Mizushima Y, Shoji Y, Hoshi K, Kiyokawa S. Detection and clinical significance of IgG rheumatoid factor. $J$ Rheumatol 1984;11:22-6.

27 Nardella FA, Mannik M: Non-immunospecific prokein-protein interactions of IgG: Studies on the binding of IgG to IgG immunoabsorbents. J Immunol 1978;120:739-44.

28 Kallerup HE, Egeskjold EM, Grandel H. IgG, IgM and IgA rheumatoid factors in healthy adults and rheumatoid patients determined by an indirect immunofluorescence method. Scand J Rheumatol 1979;8:1-9.

29 Wernick R, Merryman P, Jaffe I, Ziff M. IgG and IgM rheumatoid factors in rheumatoid arthritis: quantitative response to penicillamine therapy and relationship to disease activity. Arthritis Rheum 1983;26:593-8.

30 Rudge SR, Pound JD, Bossingham JH, Powell RJ. Class specific rheumatoid factors in rheumatoid arthritis: response to chrysotherapy and relationship to disease activity. $J$ Rheumatol 1985;12:432-6.

31 Bacon PA, Blake DR, Alexander GJM, Hall ND. Alterations in immunological parameters associated with D-penicillamine therapy. In: Maini RN, Berry H, eds. Modulation of autoimmunity and disease: the penicillamine experience. Eastbourne: Praeger, 1981:10-15.

32 Whittington RH, Seifert MH. Predominant wrist disease in rheumatoid arthritis associated with high concentrations of IgA rheumatoid factor. Br Med J 1985;291:1388.

33 Quismorio FP, Beardmore T, Kaufman RL, Mongan ES. IgG rheumatoid factors and anti-nuclear antibodies in rheumatoid vasculitis. Clin Exp Immunol 1983;52:333-40.

34 Scott DGI, Bacon PA, Allen C, Elson CJ, Wallington T. IgG rheumatoid factor, complement and immune complexes in rheumatoid synovitis and vasculitis: comparative and serial studies during cytotoxic therapy. Clin Exp Immunol 1981; 43:54-63.

35 Roberts-Thompson PJ, McEvoy R, Langhams T, Bradley J. Routine quantification of rheumatoid factor by rate nephelometry. Ann Rheum Dis 1985;44:379-83.

36 Highton J, Hession PA, Small B, Palmer DG. Clinical advantages from measurement of IgM-rheumatoid factor by enzyme immunoassay. Br J Rheumatol 1986;25:20-5.

37 Scott DL, Coulton BL, Chapman JH, Bacon PA, Popert AJ. The long-term effects of treating rheumatoid arthritis. Journal of the Royal College of Physicians 1983;17:79-85.

Requests for reprints to: Dr DL Scott, St Bartholomew's Hospital, West Smithfield, London EC1A 7BE, England. 